\title{
Toxicity of Superparamagnetic Iron Oxide Nanoparticles on Green Alga Chlorella vulgaris
}

\author{
Lotfi Barhoumi ${ }^{1,2}$ and David Dewez \\ ${ }^{1}$ Département de Chimie, Université du Québec à Montréal, CP 8888, Succursale Centre-Ville, Montréal, QC, Canada H3C 3P8 \\ ${ }^{2}$ Laboratoire de Physiologie Intégrée, Faculté des Sciences de Bizerte, Université de Carthage, Zarzouna 7021, Tunisia \\ Correspondence should be addressed to David Dewez; dewez.david@uqam.ca
}

Received 31 July 2013; Revised 29 October 2013; Accepted 4 November 2013

Academic Editor: Aiyagari Ramesh

Copyright (C) 2013 L. Barhoumi and D. Dewez. This is an open access article distributed under the Creative Commons Attribution License, which permits unrestricted use, distribution, and reproduction in any medium, provided the original work is properly cited.

\begin{abstract}
Toxicity of superparamagnetic iron oxide nanoparticles (SPION) was investigated on Chlorella vulgaris cells exposed during 72 hours to $\mathrm{Fe}_{3} \mathrm{O}_{4}$ (SPION-1), $\mathrm{Co}_{0.2} \mathrm{Zn}_{0.8} \mathrm{Fe}_{2} \mathrm{O}_{4}$ (SPION-2), or $\mathrm{Co}_{0.5} \mathrm{Zn}_{0.5} \mathrm{Fe}_{2} \mathrm{O}_{4}$ (SPION-3) to a range of concentrations from 12.5 to $400 \mu \mathrm{g} \mathrm{mL}^{-1}$. Under these treatments, toxicity impact was indicated by the deterioration of photochemical activities of photosynthesis, the induction of oxidative stress, and the inhibition of cell division rate. In comparison to SPION-2 and 3, exposure to SPION-1 caused the highest toxic effects on cellular division due to a stronger production of reactive oxygen species and deterioration of photochemical activity of Photosystem II. This study showed the potential source of toxicity for three SPION suspensions, having different chemical compositions, estimated by the change of different biomarkers. In this toxicological investigation, algal model C. vulgaris demonstrated to be a valuable bioindicator of SPION toxicity.
\end{abstract}

\section{Introduction}

Due to their physicochemical features, superparamagnetic iron oxide nanoparticles (SPION) are widely used in medical applications such as contrast agents for magnetic resonance imaging and heating mediators for cancer therapy $[1,2]$. A recent review of SPION-induced toxicity studies at cellular level in animal and human cells indicated that SPION can penetrate the cellular system by both passive diffusion and endocytosis, causing several toxic effects through the alteration of genes expressions and the generation of oxidative radicals [3]. However, their production and extensive use may contaminate aquatic environments via wastewater input, representing a risk of toxicity for different freshwater organisms. Besides endocrine disruptor and pharmaceuticals, metallic engineered nanoparticles represent one of the most important hazardous materials altering freshwater qualities. Many studies showed that the toxicity of metallic engineered nanoparticles was directly related to their surface chemistry, hydrodynamic size, chemical composition, and solubility in aqueous solution $[4,5]$. A recent study demonstrated that SPION have antibacterial properties with the ability to alter metabolic functions at a higher efficiency than antibiotics or metals salts [6]. Therefore, it is of high importance to determine the toxicity potential at cellular level of hazardous metallic nanomaterials in relation to their uptake by aquatic microorganisms. In aquatic environments, green algae represent the main source of biomass production essential for animals of higher ecological trophic levels. As being able to bioaccumulate metallic contaminants, algae can be used as a bioindicator of aquatic ecosystem health. However, bioaccumulation effects of SPION on algae have been poorly examined, and such toxicological studies were mostly done on terrestrial plant species grown hydroponically $[7,8]$. Currently, there is only one study concerning the toxic effects of $\mathrm{Fe}_{3} \mathrm{O}_{4}$ nanoparticles $(35 \mathrm{~nm})$ on the green alga Chlorella vulgaris treated $72 \mathrm{~h}$ to a nominal concentration range from 200 to $1600 \mu \mathrm{g} \mathrm{mL}^{-1}$. In this study, authors showed an induction of oxidative stress and an alteration of photosynthetic activity based on absorbed $\mathrm{CO}_{2}$ fixation [9]. Therefore, a more in-depth toxicological investigation needs to be performed to better characterise the toxicity of SPION on the cell physiology of green algae. 
In the present study, the green alga Chlorella vulgaris was used as a unicellular plant model organism for the toxicity characterisation of $\mathrm{Fe}_{3} \mathrm{O}_{4}$ (SPION-1), $\mathrm{Co}_{0.2} \mathrm{Zn}_{0.8} \mathrm{Fe}_{2} \mathrm{O}_{4}$ (SPION-2), and $\mathrm{Co}_{0.5} \mathrm{Zn}_{0.5} \mathrm{Fe}_{2} \mathrm{O}_{4}$ (SPION-3). Algal cells were exposed during 24,48 , and 72 hours in order to evaluate the evolution of SPION toxicity impact on the entire cellular system by evaluating the change in photochemical reactions of photosynthesis, cell division, and the induction of oxidative stress. This work permitted determining the risk of SPION toxicity on the viability of green algae and therefore the potential use of this algal species in a bioassay of SPION toxicity.

\section{Material and Methods}

2.1. Biological Material. The freshwater green alga Chlorella vulgaris was obtained from the Canadian Phycological Culture Centre (CPCC, University of Waterloo, ON, Canada). Algal culture was prepared in sterile BG-11 liquid growth medium $(\mathrm{pH}=7$; ionic strength $=0.0201)$ having the following final concentrations of salts composition [10]: $1.5 \mathrm{~g} \mathrm{~L}^{-1}$ of $\mathrm{NaNO}_{3}$, $0.04 \mathrm{~g} \mathrm{~L}^{-1}$ of $\mathrm{K}_{2} \mathrm{HPO}_{4} \cdot 3 \mathrm{H}_{2} \mathrm{O}, 0.075 \mathrm{~g} \mathrm{~L}^{-1}$ of $\mathrm{MgSO}_{4} \cdot 7 \mathrm{H}_{2} \mathrm{O}$, $0.036 \mathrm{~g} \mathrm{~L}^{-1}$ of $\mathrm{CaCl}_{2} \cdot 2 \mathrm{H}_{2} \mathrm{O}, 6 \times 10^{-3} \mathrm{~g} \mathrm{~L}^{-1}$ of $\mathrm{C}_{6} \mathrm{H}_{8} \mathrm{O}_{7}$ (citric acid), $6 \times 10^{-3} \mathrm{~g} \mathrm{~L}^{-1}$ of $\mathrm{C}_{6} \mathrm{H}_{5} \mathrm{FeO}_{7}$ (ferric citrate), $10^{-3} \mathrm{~g} \mathrm{~L}^{-1}$ of $\mathrm{Na}_{2}$ EDTA. $2 \mathrm{H}_{2} \mathrm{O}, \quad 0.02 \mathrm{~g} \mathrm{~L}^{-1}$ of $\mathrm{Na}_{2} \mathrm{CO}_{3}, \quad 2.86 \mathrm{mg} \mathrm{L}^{-1}$ of $\mathrm{H}_{3} \mathrm{BO}_{3}, 1.81 \mathrm{mg} \mathrm{L}^{-1}$ of $\mathrm{MnCl}_{2} \cdot 4 \mathrm{H}_{2} \mathrm{O}, 0.222 \mathrm{mg} \mathrm{L}^{-1}$ of $\mathrm{ZnSO}_{4} \cdot 7 \mathrm{H}_{2} \mathrm{O}, 0.390 \mathrm{mg} \mathrm{L}^{-1}$ of $\mathrm{Na}_{2} \mathrm{MoO}_{4} \cdot 2 \mathrm{H}_{2} \mathrm{O}, 0.079 \mathrm{mg} \mathrm{L}^{-1}$ of $\mathrm{CuSO}_{4} \cdot 5 \mathrm{H}_{2} \mathrm{O}$, and $0.0494 \mathrm{mg} \mathrm{L}^{-1}$ of $\mathrm{Co}\left(\mathrm{NO}_{3}\right)_{2} \cdot 6 \mathrm{H}_{2} \mathrm{O}$. Algal cells were grown under continuous light intensity of $100 \mu \mathrm{mol} \mathrm{m}^{-2} \mathrm{~s}^{-1}$ (SYLVANIA GRO-LUX Wide Spectrum light $\mathrm{F} 40 / \mathrm{GRQ} / \mathrm{AQ} / \mathrm{WS}$ ) at $24^{\circ} \mathrm{C} \pm 1$. Aliquots of algal samples were used for experiments when algal culture reached the exponential growth phase. The change of cell density was determined by monitoring the optical density at $750 \mathrm{~nm}$, and the calculation was based on a standard correlation with the cell density measured using a multisizer Z3 (Beckman Coulter Inc., USA).

2.2. Synthesis of SPION. Superparamagnetic iron oxide nanoparticles (SPION) as $\mathrm{Fe}_{3} \mathrm{O}_{4}$ (SPION-1), $\mathrm{Co}_{0.2} \mathrm{Zn}_{0.8} \mathrm{Fe}_{2} \mathrm{O}_{4}$ (SPION-2), and $\mathrm{Co}_{0.5} \mathrm{Zn}_{0.5} \mathrm{Fe}_{2} \mathrm{O}_{4}$ (SPION-3) were produced according to the procedure reported in [11], by using the polyol process starting from $\mathrm{Co}\left(\mathrm{CH}_{3} \mathrm{CO}_{2}\right)_{2} \bullet 4 \mathrm{H}_{2} \mathrm{O}, \mathrm{Zn}$ $\left(\mathrm{CH}_{3} \mathrm{CO}_{2}\right)_{2} \cdot 2 \mathrm{H}_{2} \mathrm{O}$ and $\mathrm{Fe}\left(\mathrm{CH}_{3} \mathrm{CO}_{2}\right)_{2}$ as precursor salts and diethylene glycol as a solvent.

2.3. Stock Solution and SPION Characterization. In the preparation of stock solutions, SPION were suspended in culture medium at a concentration of $1 \mathrm{~g} \mathrm{~L}^{-1}$ and homogenized by ultrasonication during $30 \mathrm{~min}$ at $4^{\circ} \mathrm{C}$ to break up agglomerates. After sonication, stock solutions were mix with a vortex for $1 \mathrm{~min}$, and various concentrations of SPION were prepared in culture medium for experiments. Size distribution was determined by dynamic light scattering (DLS) with a ZetaPlus particle sizer (Brookhaven Instrument Corporation, USA) using 90Plus Particles Sizing Software (Ver. 4.20). Zeta potential of SPION suspensions in culture medium was

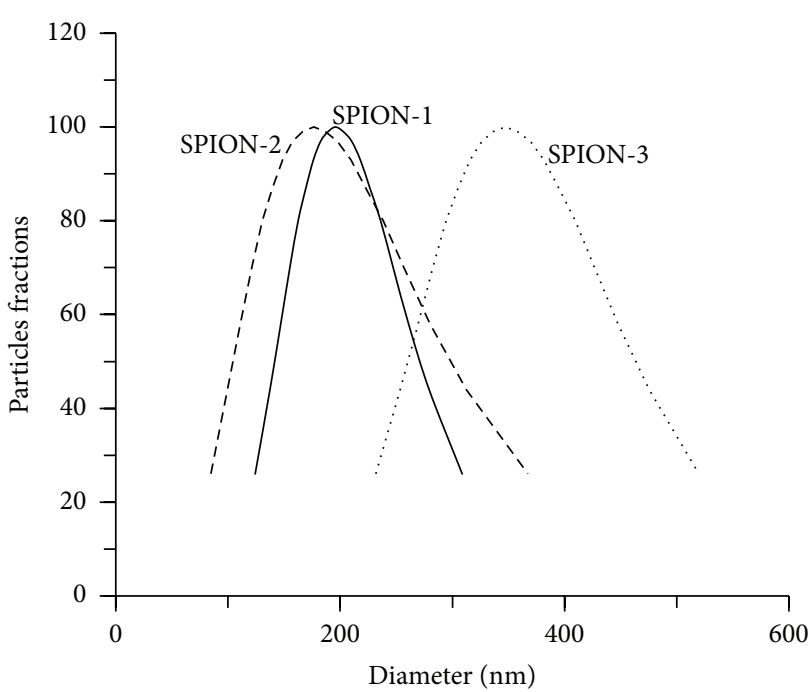

FIgure 1: Particle size distribution of SPION-1 $\left(\mathrm{Fe}_{3} \mathrm{O}_{4}\right)$, SPION-2 $\left(\mathrm{Co}_{0.2} \mathrm{Zn}_{0.8} \mathrm{Fe}_{2} \mathrm{O}_{4}\right)$, and SPION-3 $\left(\mathrm{Co}_{0.5} \mathrm{Zn}_{0.5} \mathrm{Fe}_{2} \mathrm{O}_{4}\right)$ suspensions in the culture medium.

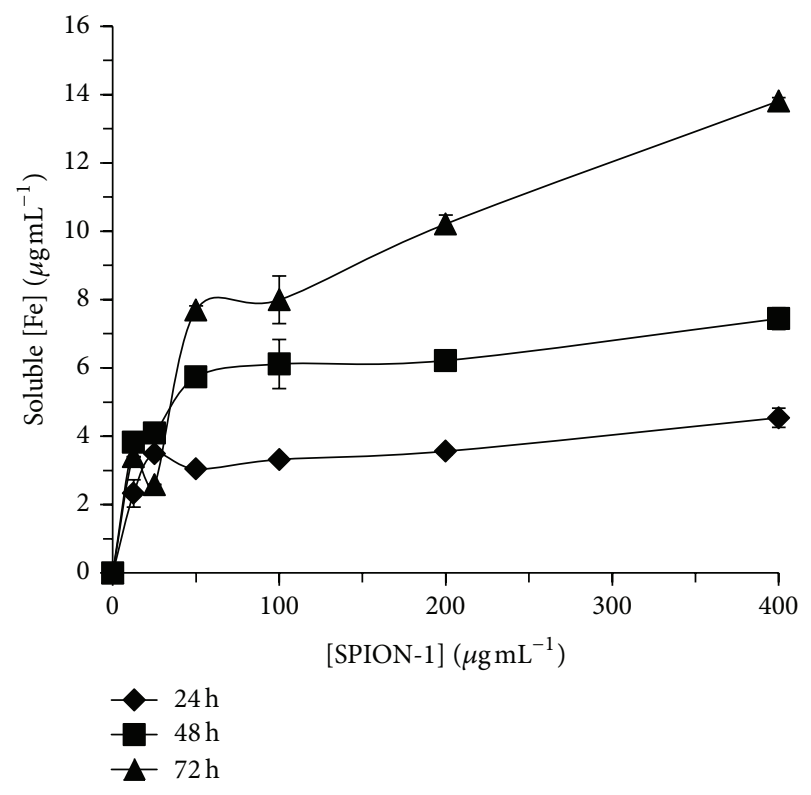

FIGURE 2: Soluble fraction of free Fe released from SPION-1 $\left(\mathrm{Fe}_{3} \mathrm{O}_{4}\right)$ suspension in culture medium at 24,48 , and $72 \mathrm{~h}$ of exposure.

evaluated by the electrophoretic mobility method with the ZetaPlus system.

2.4. Experimental Treatments. In each treatment condition, the initial density of algal cells was of $10^{6}$ cells $\mathrm{mL}^{-1}$ in a final volume of $50 \mathrm{~mL}$. Algal samples were exposed during 24, 48, and $72 \mathrm{~h}$ to $12.5,25,50,100,200$, and $400 \mathrm{mg} \mathrm{L}^{-1}$ of SPION1, SPION-2, or SPION-3, under the same illumination and temperature condition used for growing stock cultures. For the control sample, the same media composition was used but without any trace of SPION. 


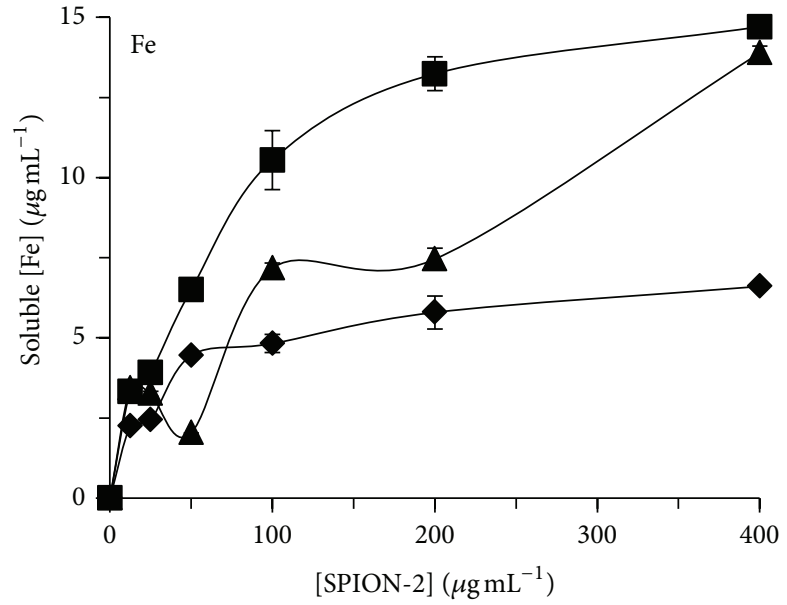

(a)

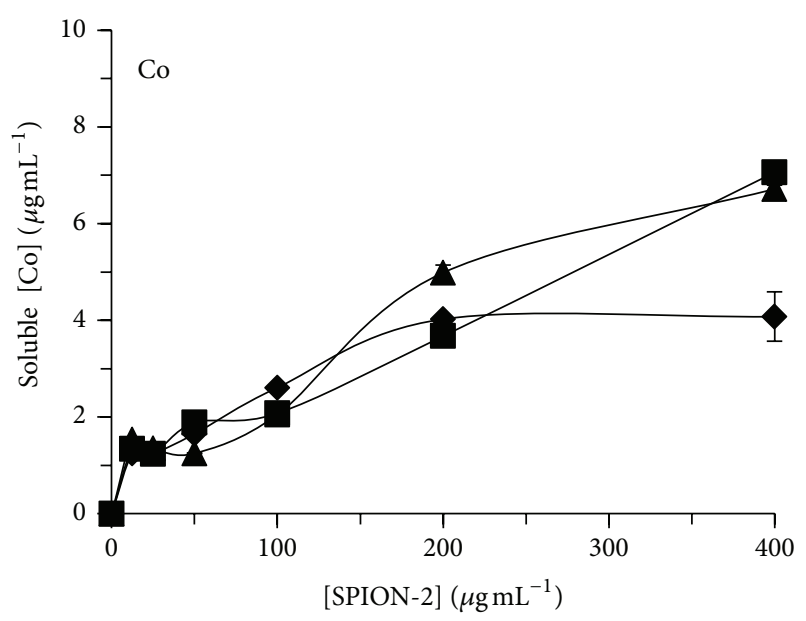

(b)

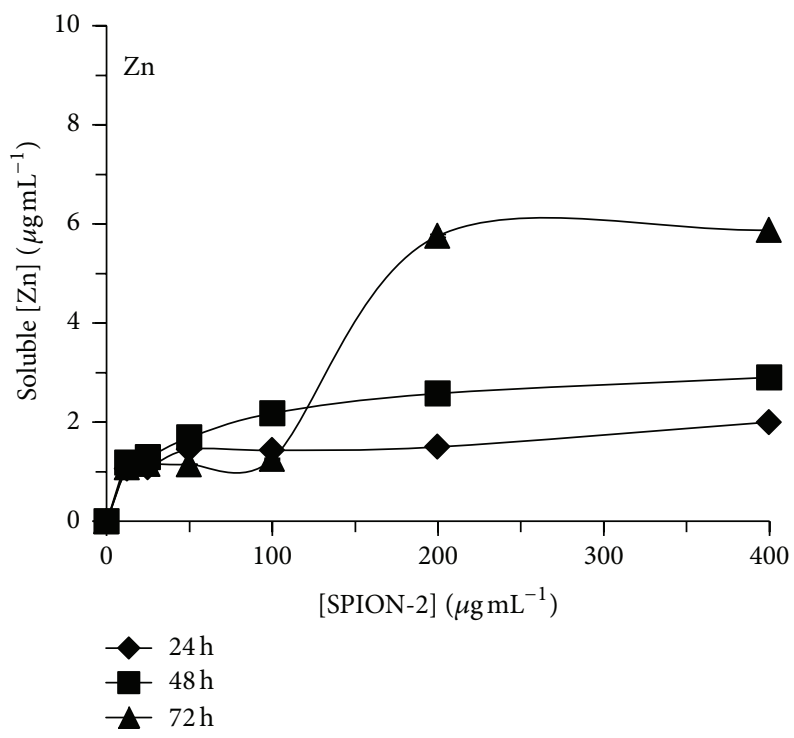

(c)

Figure 3: Soluble fraction of free $\mathrm{Fe}, \mathrm{Co}$, and $\mathrm{Zn}$ released from SPION-2 $\left(\mathrm{Co}_{0.2} \mathrm{Zn}_{0.8} \mathrm{Fe}_{2} \mathrm{O}_{4}\right)$ suspension in culture medium at 24,48 , and $72 \mathrm{~h}$ of exposure.

2.5. Growth Inhibition Test. The relative cell division rate (RCDR) was evaluated for $72 \mathrm{~h}$ according to [12], as RCDR = $\left(\ln \mathrm{W}_{72 \mathrm{~h}}-\ln \mathrm{W}_{0}\right) / 72 \mathrm{~h}$, where $\mathrm{W}_{72 \mathrm{~h}}$ represents cell density at $72 \mathrm{~h}$ and $\mathrm{W}_{0}$ the initial cell density.

2.6. Bioaccumulation of Fe, Co, and $\mathrm{Zn}$. To separate SPION from cells, a sucrose gradient prepared in BG-11 media was done directly in a Beckman centrifuge tube inclined at a $30^{\circ}$ angle in order to get 6 layers of different sucrose densities $(5 \mathrm{~mL}$ of each sucrose solution $120,100,80,60,40$, and $20 \%)$. Algal cells of control and SPION-treated samples were collected by centrifugation. Their pellets were slowly placed on top of sucrose gradient tubes which were centrifuged at $1,000 \mathrm{rpm}$ during $30 \mathrm{~min}$ in a swinging-bucket $5810 \mathrm{R}$ centrifuge (Eppendorf, Germany). It resulted in the formation of a pellet of SPION at the bottom of the tube. The algal cells layer was recuperated with a glass Pasteur pipette and filtered on a $0.45 \mu \mathrm{m}$ filter previously dried and weighted. To remove SPION weakly bound to the cell surface or the filter, $3 \times 10 \mathrm{~mL}$ of $10 \mathrm{mM}$ ethylenediaminetetraacetic acid in BG-11 medium was slowly passed through the filter. Filters were dried at $95^{\circ} \mathrm{C}$ for $24 \mathrm{~h}$ and weighted to calculate algal dry weight. Filters were then placed in acid-washed glass tubes in which $4 \mathrm{~mL}$ of $\mathrm{HNO}_{3}$ and $500 \mu \mathrm{L} \mathrm{H}_{2} \mathrm{O}_{2}$ were added. Samples were digested during $48 \mathrm{~h}$ at room temperature before being diluted to $20 \%$ $\mathrm{HNO}_{3}$ in Milli-Q purified water for the quantification of Fe, $\mathrm{Co}$, and $\mathrm{Zn}$ using atomic absorption spectrometry analysis (Varian SpectrAA 220 FS, USA). Obtained Fe, Co, and Zn concentrations were normalized to the dry weight.

2.7. Soluble Fraction of $\mathrm{Fe}, \mathrm{Co}$, and $\mathrm{Zn}$. Solubility of free Fe, $\mathrm{Co}$, and $\mathrm{Zn}$ released from SPION suspensions were determined in culture medium. SPION suspensions was incubated during 24,48 , and $72 \mathrm{~h}$ in the same condition as described 


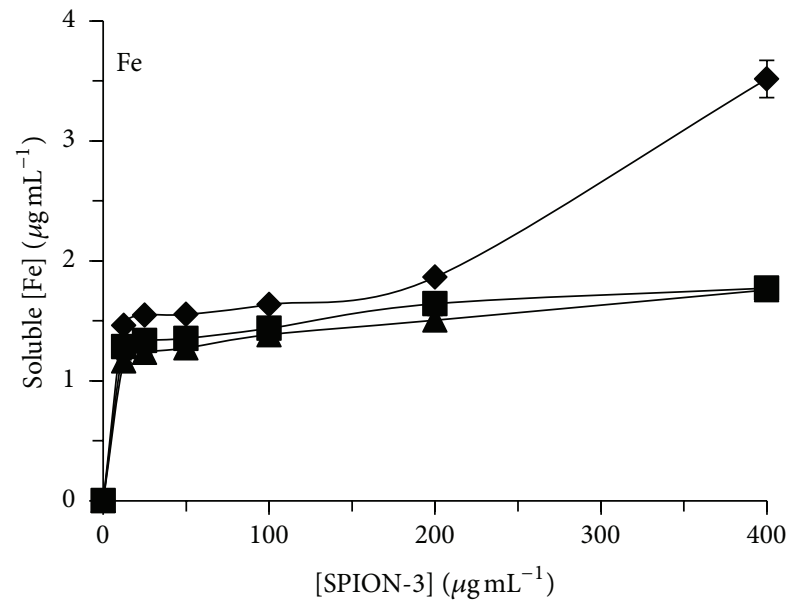

(a)

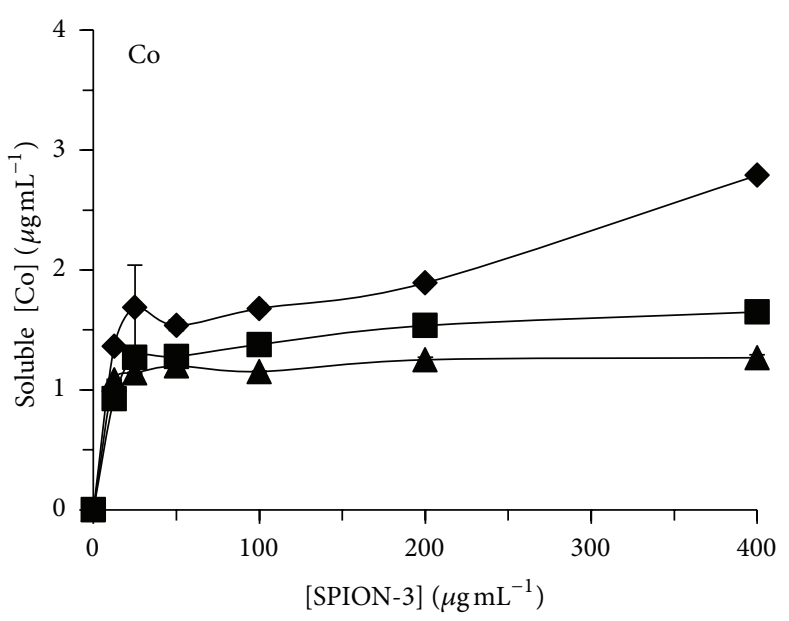

(b)

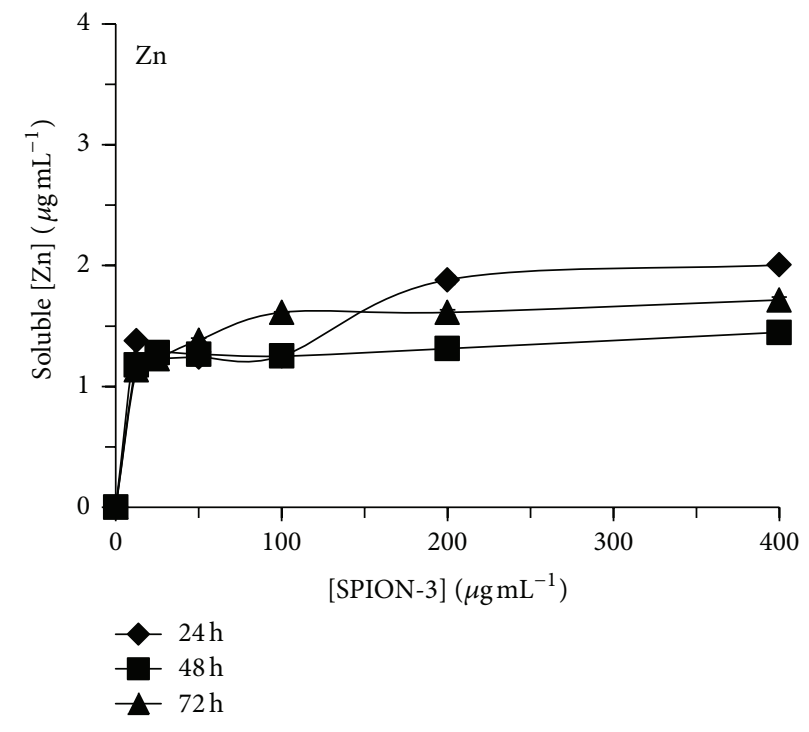

(c)

FIGURE 4: Soluble fraction of Fe, Co, and $\mathrm{Zn}$ released from SPION-3 $\left(\mathrm{Co}_{0.5} \mathrm{Zn}_{0.5} \mathrm{Fe}_{2} \mathrm{O}_{4}\right)$ suspension in culture medium at 24, 48, and $72 \mathrm{~h}$ of exposure.

above for treatment. After incubation, NPs were removed by centrifugation at 12,000 $\mathrm{g}$ for $30 \mathrm{~min}$ and the supernatant was collected for analysis. Quantification of free Fe, Co, and $\mathrm{Zn}$ in solution was measured by atomic absorption spectrometry (Varian SpectrAA 220 FS, USA).

2.8. Production of ROS. The fluorescent dye $2^{\prime}, 7^{\prime}$-dichlorodihydrofluorescein diacetate $\left(\left(\mathrm{H}_{2} \mathrm{DCFDA}\right)\right.$ Invitrogen Molecular Probe, USA) was used as an indicator of ROS according to [13]. Cellular esterases hydrolyze this probe into the nonfluorescent compound $2^{\prime}, 7^{\prime}$-dichlorodihydrofluorescein $\left(\mathrm{H}_{2} \mathrm{DCF}\right)$, which is better retained within cells. In the presence of ROS and cellular esterases, $\mathrm{H}_{2} \mathrm{DCF}$ is transformed into the highly fluorescent compound $2^{\prime}, 7^{\prime}$-dichlorofluorescein (DCF). $\mathrm{H}_{2}$ DCFDA stock solution $(10 \mathrm{mM})$ was prepared in ethanol in the dark. After $72 \mathrm{~h}$ of treatment, $1 \mathrm{~mL}$ of algal samples was exposed during $15 \mathrm{~min}$ to $0.2 \mathrm{mM}$ of
$\mathrm{H}_{2}$ DCFDA in the dark. The ROS level was determined by measuring the fluorescence emission at $530 \mathrm{~nm}$ with a flow cytometer (FACScan system, Becton Dickinson Instruments, USA). Cytometry results were analysed using the WinMDI 2.8 software. Algal cells were separated from noncellular particles by using a relationship between particle size and red fluorescence level, originating from chlorophyll fluorescence emission. A positive control sample using methyl viologen was done to verify the assay (data not shown).

2.9. Cellular Viability. Viability of algal cells was estimated using the fluorescein diacetate ((FDA) Invitrogen Molecular Probe, USA) method according to [14]. FDA is a nonpolar ester compound which passes through cell membranes. Once inside the cell, FDA is hydrolyzed by esterases (enzymes present in viable cells) to produce fluorescein, accumulating in cell wall and emitting fluorescence under UV illumination. 
After $72 \mathrm{~h}$ of treatment, $1 \mathrm{~mL}$ of algal samples was exposed during $15 \mathrm{~min}$ to $0.2 \mathrm{mM}$ of FDA in the dark. Cell viability was determined by measuring the fluorescence emission at $530 \mathrm{~nm}$ with a flow cytometer (FACScan System, Becton Dickinson Instruments, USA). Cytometry results were analysed using the WinMDI 2.8 software. Algal cells were separated from noncellular particles by using a relationship between particle size and red fluorescence level, originating from chlorophyll fluorescence emission. A positive control sample using methyl viologen was done to verify the assay (data not shown).

2.10. Chl a Fluorescence Emission. Photosynthetic electron transport was monitored from the change in the rapid rise of Chl $a$ fluorescence emission using a "Plant Efficiency Analyser" fluorometer (Handy-PEA, Hansatech Ltd., UK). Total chlorophyll $(\mathrm{Chl})$ content $(a+b)$ was extracted in $100 \%$ methanol at $65^{\circ} \mathrm{C}$ and quantified with a spectrophotometer (Lambda 40, Perkin-Elmer, USA) according to the formula indicated in [15]: Total Chl $\left(\mu \mathrm{g} \mathrm{mL}^{-1}\right)=\left(24.93 \times \mathrm{A}_{652.4}+\right.$ $\left.1.44 \times \mathrm{A}_{665.2}\right)$.

Prior to fluorescence measurements, algal samples were transferred into clean sterile $2 \mathrm{~mL}$ glass vials and darkadapted for $30 \mathrm{~min}$. An aliquot of $5 \mu \mathrm{g}$ of total chlorophyll was gently filtered using low pressure filtration and algal cells were uniformly placed on a $13 \mathrm{~mm}$ glass fibre filter (Millipore, USA). The fluorescence induction was triggered using a $1 \mathrm{~s}$ saturating flash of $3500 \mu \mathrm{mol} \mathrm{m}{ }^{-2} \mathrm{~s}^{-1}$. The fluorescence intensity at $20 \mu$ s was considered as the $O$ value $\left(F_{O}\right)$; fluorescence intensities for $K, J$, and $I$ transients were determined at $300 \mu \mathrm{s}\left(F_{K}\right), 2 \mathrm{~ms}\left(F_{I}\right)$, and $30 \mathrm{~ms}\left(F_{I}\right)$, respectively. the maximum fluorescence yield reached maximal value of fluorescence intensity $\left(F_{M}\right)$ under saturating illumination. Different photosynthetic-based fluorescence parameters related to the functional state of Photosystem II were calculated $[16,17]$ : the maximum efficiency of PSII electron transport, $F_{V} / F_{M}=$ $\left(F_{M}-F_{\mathrm{O}}\right) / F_{M}$; the absorption of photons by light harvesting antenna complexes (ABS) per active reaction center (RC), $\mathrm{ABS} / \mathrm{RC}=\left(\left(F_{K}-F_{\mathrm{O}}\right) / 0.25\right) \times\left(1 /\left(F_{J}-F_{\mathrm{O}}\right)\right) \times\left(F_{M} /\left(F_{M}-\right.\right.$ $\left.\left.F_{O}\right)\right)$; the relative variable fluorescence yield at $J$ transient, estimating the fraction of $Q_{A}$ in its reduced state, $V_{J}=$ $\left(F_{J}-F_{O}\right) /\left(F_{M}-F_{O}\right)$; and the performance index of PSII photosynthetic activity, P.I. $=\mathrm{RC} / \mathrm{ABS} \times\left(\left(F_{M}-F_{O}\right) / F_{\mathrm{O}}\right) \times$ $\left(\left(1-V_{J}\right) / V_{J}\right)$.

2.11. Statistical Analysis. All treatments were performed in triplicate. Means and standard deviations were calculated for each treatment. Significant differences between control and treated plants were determined by one-way analysis of variance (ANOVA) followed by a Dunnett's multiple comparison (DMC) test where $P$ value less than 0.05 was considered significant.

\section{Results}

3.1. Characterisation of SPION. When SPION were suspended in the media, nanoparticles formed agglomerates during the first minutes, as indicated by the distribution

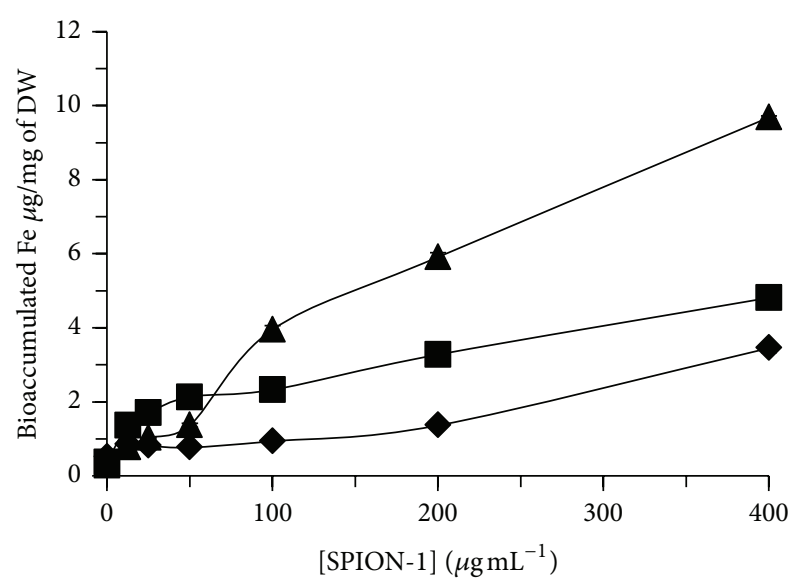

Figure 5: Bioaccumulated content of Fe in algal cells of Chlorella

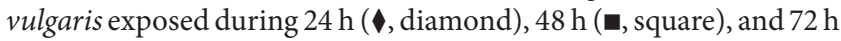
$\left(\boldsymbol{\Lambda}\right.$, triangle) to different concentrations of SPION-1 $\left(\mathrm{Fe}_{3} \mathrm{O}_{4}\right)$.

of hydrodynamic particles size diameter, which was caused by the content of salts in the media. Analysis by dynamic light scattering showed SPION-1, SPION-2, and SPION-3 suspensions in culture media to have an average diameter of particle size distribution of 195.9, 176.5, and $347.2 \mathrm{~nm}$, respectively (Figure 1). These distributions of hydrodynamic size of SPION were found to be stable in the culture medium during the entire experimental exposure. Furthermore, measurements of zeta potential $(\mathrm{mV})$ indicated that SPION were negatively charged in the media with values of $-25.68( \pm 1.38)$, $-29.14( \pm 3.85)$, and $-28.06( \pm 1.19)$, respectively, for SPION-1, SPION-2, and SPION-3.

3.2. Solubility and Bioaccumulation of SPION. The soluble fraction of free $\mathrm{Fe}, \mathrm{Co}$, and $\mathrm{Zn}$ released from SPION-1, SPION-2, and SPION-3 suspensions in culture medium was determined at 24, 48, and 72 hours (Figures 2, 3, and 4). The quantity of soluble $\mathrm{Fe}, \mathrm{Co}$, and $\mathrm{Zn}$ in the medium was dependent on the time of exposure, the SPION composition, and their concentration. When C. vulgaris was exposed to $12.5 \mu \mathrm{g} \mathrm{mL}^{-1}$ of SPION-1 $\left(\mathrm{Fe}_{3} \mathrm{O}_{4}\right)$ during $72 \mathrm{~h}$, the proportion of the soluble fraction of free Fe was of $27 \%$ compared to the nominal concentration of SPION-1, and it decreased to $3 \%$ for $400 \mu \mathrm{g} \mathrm{mL}^{-1}$ of SPION-1 (Figure 2). However, the solubility of SPION-2 $\left(\mathrm{Co}_{0.2} \mathrm{Zn}_{0.8} \mathrm{Fe}_{2} \mathrm{O}_{4}\right)$ was dependent on the metal species. When algal cells were exposed during $72 \mathrm{~h}$ to $12.5 \mu \mathrm{g} \mathrm{mL}^{-1}$ of SPION-2, proportions of free Fe, $\mathrm{Co}$, and $\mathrm{Zn}$ in the soluble fraction were, respectively, of 27,12 , and $9 \%$ compared to the nominal concentration of SPION-2 (Figure 3). For the exposure concentration of $400 \mu \mathrm{g} \mathrm{mL}^{-1}$, the quantity of soluble $\mathrm{Fe}, \mathrm{Co}$, and $\mathrm{Zn}$ decreased to 3,2 , and $1 \%$, respectively. Concerning the solubility of SPION-3 $\left(\mathrm{Co}_{0.5} \mathrm{Zn}_{0.5} \mathrm{Fe}_{2} \mathrm{O}_{4}\right)$, concentrations of $\mathrm{Fe}, \mathrm{Co}$, and $\mathrm{Zn}$ in the soluble fraction at $72 \mathrm{~h}$ were of $9 \%$ each when compared to the nominal concentration of $12.5 \mu \mathrm{g} \mathrm{mL}^{-1}$. For the exposure concentration of $400 \mu \mathrm{g} \mathrm{mL}^{-1}$, concentrations of $\mathrm{Fe}, \mathrm{Co}$, and $\mathrm{Zn}$ in the soluble fraction were less than 


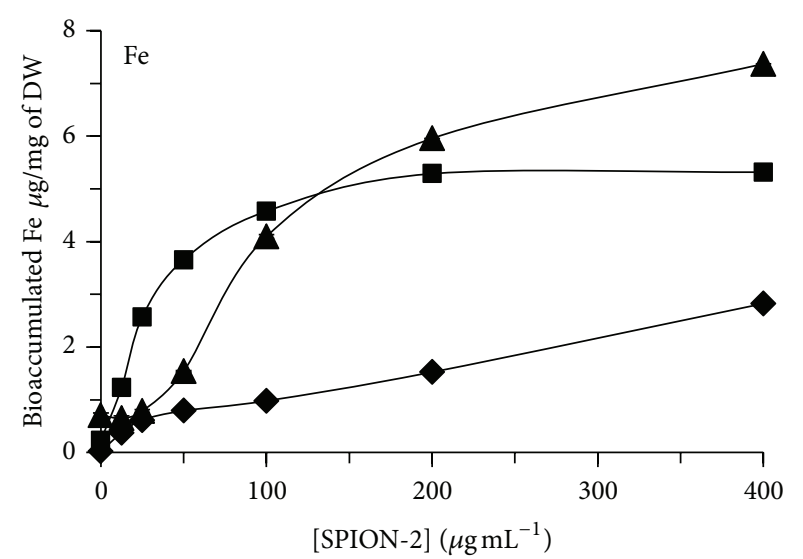

(a)

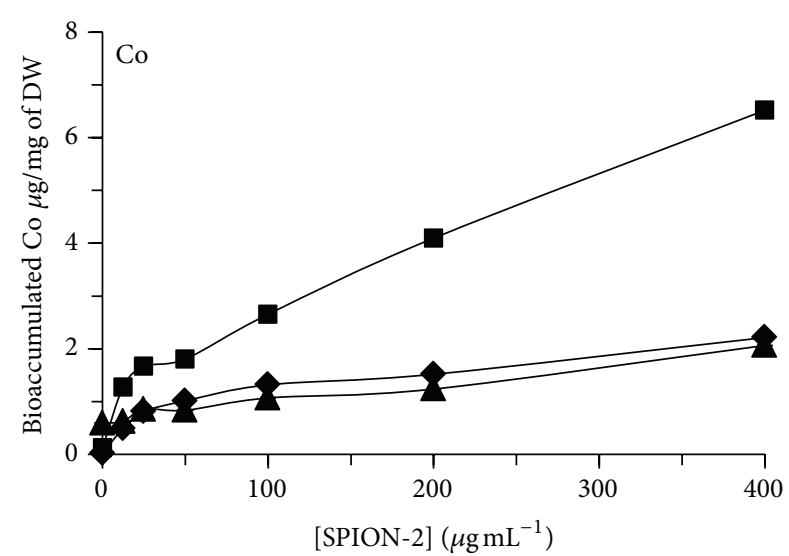

(b)

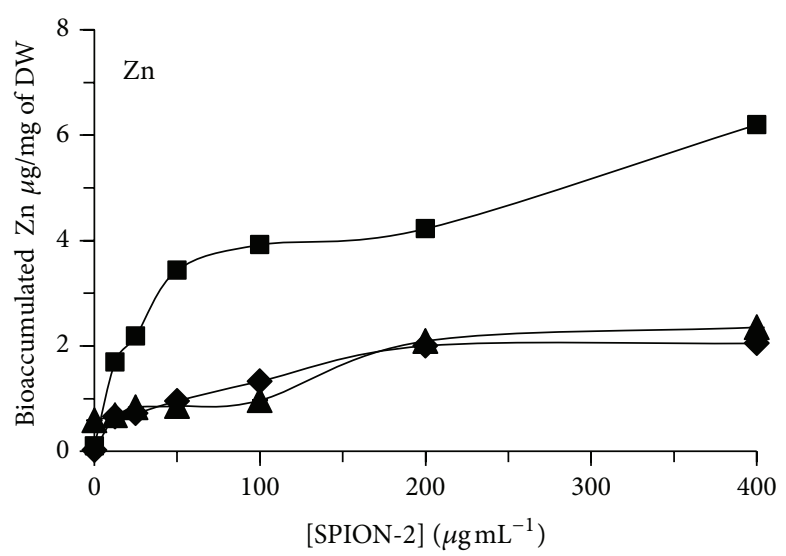

(c)

Figure 6: Bioaccumulated content of $\mathrm{Fe}, \mathrm{Co}$, and $\mathrm{Zn}$ in algal cells of Chlorella vulgaris exposed during $24 \mathrm{~h}(\boldsymbol{}$, diamond), $48 \mathrm{~h}(\mathbf{\square}$, square), and $72 \mathrm{~h}(\boldsymbol{\Lambda}$, triangle $)$ to different concentrations of SPION-2 $\left(\mathrm{Co}_{0.2} \mathrm{Zn}_{0.8} \mathrm{Fe}_{2} \mathrm{O}_{4}\right)$.

$0.5 \%$ in comparison to the nominal concentration of SPION3. Indeed, we observed that the agglomeration of SPION increased their precipitation/sedimentation at the bottom of the experimental flask, which was directly related to the increasing concentration tested and time of exposure. This effect may cause the reduction of the surface contact of nanoparticles with the medium explaining the decrease in SPION solubilisation related to their concentration and time of exposure.

The bioaccumulation of total Fe, Co, and $\mathrm{Zn}$ was also quantified in algal biomass of C. vulgaris exposed during 24, 48 , and $72 \mathrm{~h}$ to SPION (Figures 5, 6, and 7). For SPION-1, the accumulated contents of $\mathrm{Fe}$ in algal biomass increased in dependence on the concentration of SPION and the time of exposure (Figure 5). The bioaccumulated content of Fe increased by 35-fold for algal cells treated during $72 \mathrm{~h}$ to $400 \mu \mathrm{g} \mathrm{mL}^{-1}$ of SPION-1 compared to control. Under this treatment condition, Fe bioaccumulation increased by $2.81-$ fold from 24 to $72 \mathrm{~h}$. Concerning SPION-2, the accumulated contents of $\mathrm{Fe}, \mathrm{Co}$, and $\mathrm{Zn}$ increased in algal biomass in relation to the concentration of SPION (Figure 6). The content of $\mathrm{Fe}$ reached its maximum value at $72 \mathrm{~h}$ which increased by 10.4 -fold for $400 \mu \mathrm{g} \mathrm{mL}^{-1}$ of SPION compared to control. On the other hand, the contents of Co and $\mathrm{Zn}$ attained their maximal values at $48 \mathrm{~h}$ which increased, respectively, by 53.7 -and 62.8 -fold for $400 \mu \mathrm{g} \mathrm{mL}^{-1}$ of SPION compared to control. When $C$. vulgaris was exposed to SPION-3, the bioaccumulation of Fe, Co, and $\mathrm{Zn}$ increased in relation to the concentration of SPION (Figure 7). At $72 \mathrm{~h}$ of exposure, values of $\mathrm{Fe}, \mathrm{Co}$, and $\mathrm{Zn}$ contents increased, respectively, by 4.42-, 3.29-, and 5.47-fold for $400 \mu \mathrm{g} \mathrm{mL}^{-1}$ of SPION compared to control.

3.3. Inhibition of the Relative Cell Division Rate. When algal cells of C. vulgaris were exposed during $72 \mathrm{~h}$ to SPION at concentrations varying from 12.5 to $400 \mu \mathrm{g} \mathrm{mL}^{-1}$, the inhibition of the relative cell division rate based on the change of cell density was dependent on the tested SPION concentration (Table 1). Under concentration exposure of $400 \mu \mathrm{g} \mathrm{mL}^{-1}$, the relative cell division rate decreased significantly compared to the control by $47.8,21.8$, and $15.8 \%$ for SPION-1, SPION-2, and SPION-3, respectively.

3.4. Inhibition of Photosynthetic Electron Transport. The change of Chl $a$ fluorescence emission was used to monitor the photosynthetic electron transport when algal cells of 


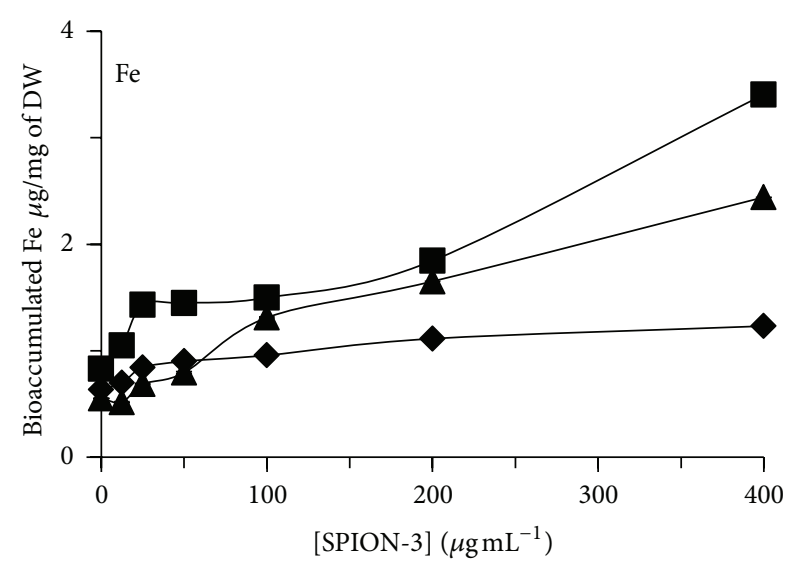

(a)

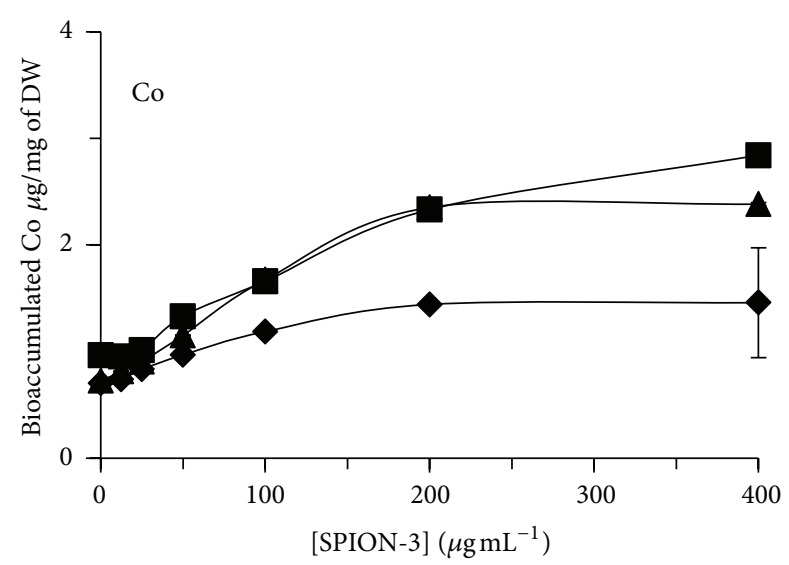

(b)

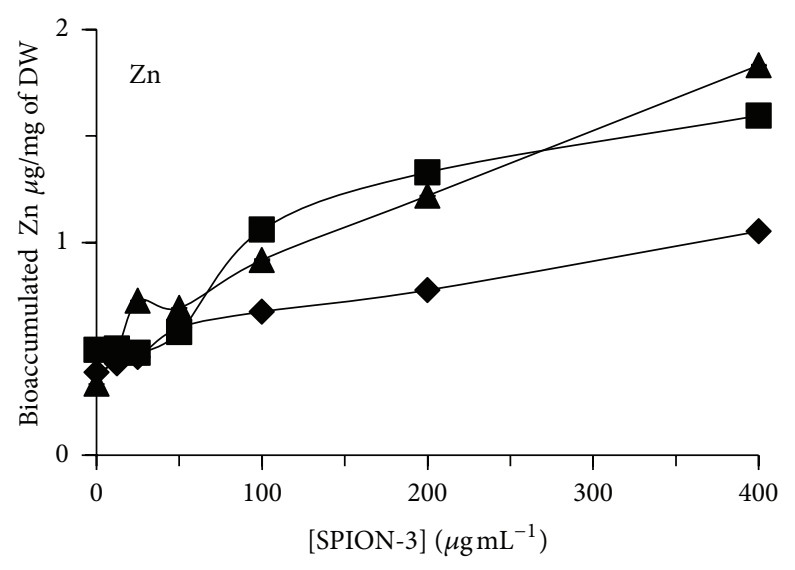

(c)

Figure 7: Bioaccumulated content of Fe, Co, and $\mathrm{Zn}$ in algal cells of Chlorella vulgaris exposed during $24 \mathrm{~h}(\boldsymbol{}$, diamond), $48 \mathrm{~h}$ ( $\mathbf{\square}$, square), and $72 \mathrm{~h}\left(\boldsymbol{\Lambda}\right.$, triangle) to different concentrations of SPION-3 $\left(\mathrm{Co}_{0.5} \mathrm{Zn}_{0.5} \mathrm{Fe}_{2} \mathrm{O}_{4}\right)$.

TABLE 1: Change in the relative cell division rate (RCDR) when $C$. vulgaris was exposed to SPION during $72 \mathrm{~h}$.

\begin{tabular}{lccc}
\hline $\begin{array}{l}\text { [SPION] } \\
\mu \mathrm{g} / \mathrm{mL}\end{array}$ & SPION-1 & $\begin{array}{c}\text { RCDR }\left(10^{-6}\right) \\
\text { SPION-2 }\end{array}$ & SPION-3 \\
\hline 0 & $0.335 \pm 0.01$ & $0.335 \pm 0.01$ & $0.335 \pm 0.01$ \\
12.5 & $0.305 \pm 0.05$ & $0.307 \pm 0.05$ & $0.317 \pm 0.004$ \\
25 & $0.308 \pm 0.008$ & $0.298 \pm 0.006$ & $0.318 \pm 0.007$ \\
50 & $0.307 \pm 0.02$ & $0.297 \pm 0.018$ & $0.309 \pm 0.004$ \\
100 & $0.266 \pm 0.05$ & $0.291 \pm 0.007$ & $0.306 \pm 0.025$ \\
200 & $0.220 \pm 0.008$ & $0.264 \pm 0.002$ & $0.286 \pm 0.005$ \\
400 & $0.175 \pm 0.123$ & $0.262 \pm 0.0033$ & $0.282 \pm 0.004$ \\
\hline
\end{tabular}

C. vulgaris were exposed during $72 \mathrm{~h}$ to SPION toxicity. The kinetics of Chl $a$ fluorescence indicated a decrease of fluorescence yields at $J, I$, and $M$ levels without any change in their time of appearance, which was related to SPION concentration (See Supplementary Figures available online at http://dx.doi.org/10.1155/2013/647974). Furthermore, the change of photosynthetic-fluorescence parameters estimated from the fluorescence kinetic was used as biomarkers of SPION effect on PSII photochemistry (Figure 8). The strongest effect on photosynthetic electron transport was observed under $400 \mu \mathrm{g} \mathrm{mL} \mathrm{m}^{-1}$ of SPION treatment. Under this condition, the value of ABS/RC parameter increased significantly compared to the control by 43,29 , and $81 \%$ for SPION-1, SPION-2, and SPION-3, respectively. This change indicated a decrease of functional PSII reaction centers able to perform photochemical reactions. Also, $V_{J}$ values, indicating the level of $\mathrm{Q}_{\mathrm{A}}{ }^{-} / \mathrm{Q}_{\mathrm{A}(\text { total) }}$, increased significantly compared to the control by 32,23 , and $12 \%$, respectively, for SPION-1, SPION-2, and SPION-3, due to the inhibition of PSII electron transport flow toward to plastoquinone pool. However, the maximal quantum yield of PSII $\left(F_{V} / F_{M}\right)$ decreased by 14,12 , and $35 \%$, respectively, for SPION-1, SPION-2, and SPION3. Moreover, the PSII performance index, P.I., was used as a global parameter integrating all PSII photochemical reactions from light harvesting energy transfer to electron transport. When algal cells of C. vulgaris were exposed during $72 \mathrm{~h}$ to $400 \mu \mathrm{g} \mathrm{mL}^{-1}$ of SPION, P.I. values decreased significantly compared to the control by 78,65 , and $85 \%$ for SPION-1, SPION-2, and SPION-3, respectively. 


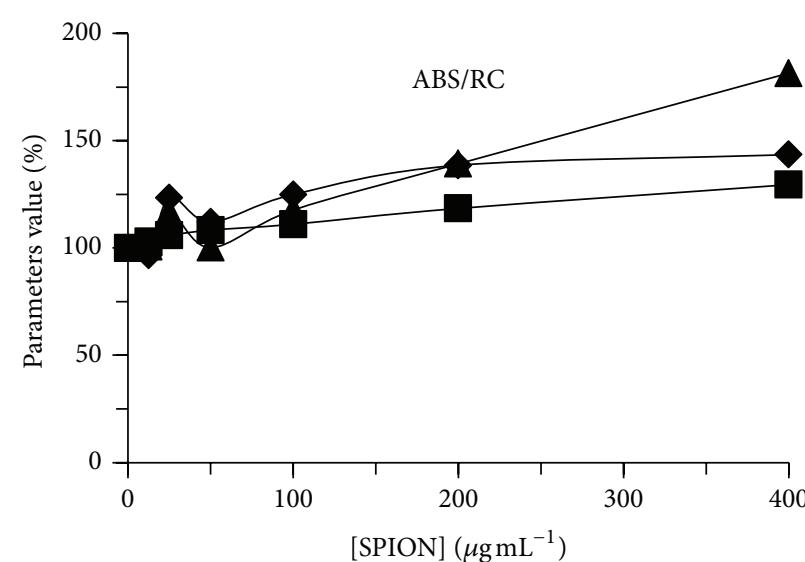

(a)

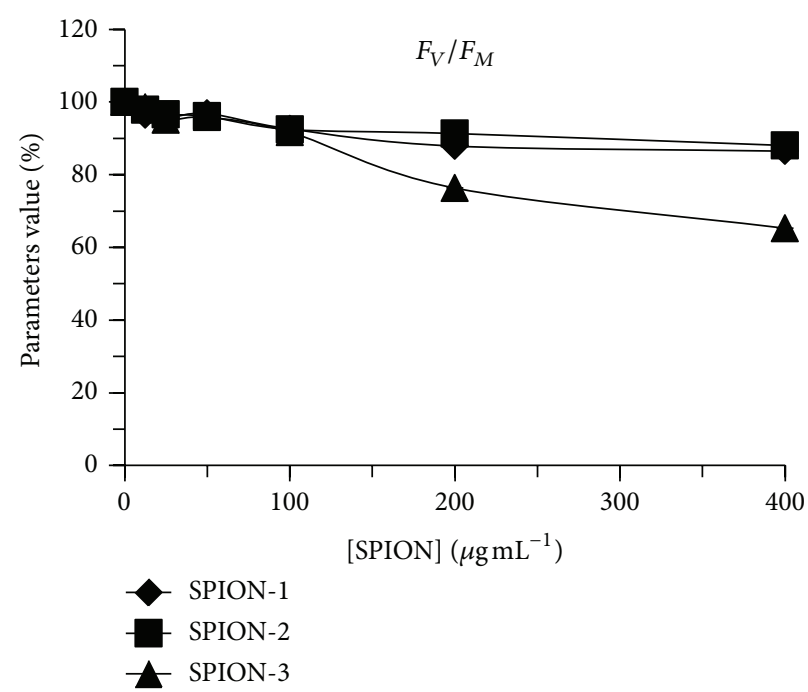

(c)

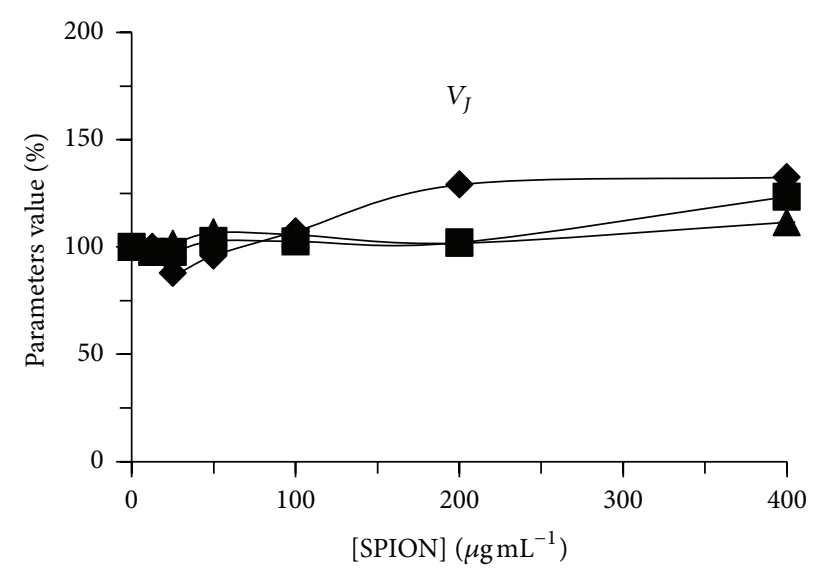

(b)

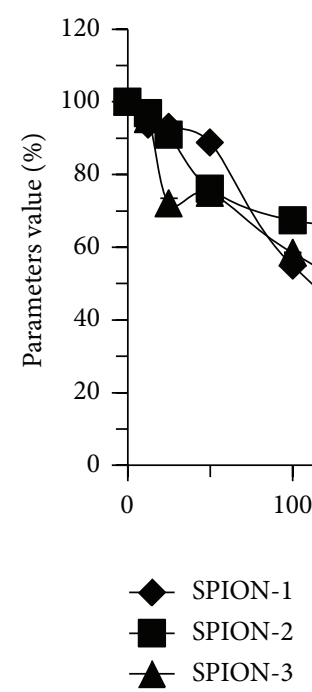

P.I.

(d)

FiguRE 8: Change of different photosynthetic-based fluorescence parameters for algal cells of Chlorella vulgaris exposed during $72 \mathrm{~h}$ to different concentrations of SPION-1 $\left(\mathrm{Fe}_{3} \mathrm{O}_{4}\right)$, SPION-2 $\left(\mathrm{Co}_{0.2} \mathrm{Zn}_{0.8} \mathrm{Fe}_{2} \mathrm{O}_{4}\right)$, and SPION-3 $\left(\mathrm{Co}_{0.5} \mathrm{Zn}_{0.5} \mathrm{Fe}_{2} \mathrm{O}_{4}\right)$. Maximal PSII quantum yield: $F_{V} / F_{M}$; ratio between the number of active PSII reaction centers and light harvesting Chl antenna size: ABS/RC; relative variable fluorescence yield at $J$ transient: $V_{J}$; performance index of PSII photochemical activity: P.I.

3.5. Production of Reactive Oxygen Species Related to Cell Viability. The formation of ROS per viable cells was determined for C. vulgaris exposed during $72 \mathrm{~h}$ to SPION (Figure 9). Under these conditions, cell viability decreased significantly compared to control from $50 \mu \mathrm{g} \mathrm{mL}^{-1}$ of SPION, indicating an induction of cellular oxidative stress. The production of ROS per viable cells increased significantly compared to control which was dependent on SPION species and concentration.

\section{Discussion}

4.1. Toxicity of SPION-1, SPION-2, and SPION-3. In this study, toxic effects of SPION-1, -2 , and -3 were investigated on algal cells of $C$. vulgaris, which were caused by the deterioration of photochemical activities of photosynthesis, the induction of oxidative stress, and the inhibition of cell division rate. This complex cellular alteration was dependent on SPION chemical composition and its concentration in solution. Based on our results, it is evident that the bioaccumulation of free $\mathrm{Fe}, \mathrm{Co}$, and $\mathrm{Zn}$ from the soluble fraction was contributing to the toxicity impact in algal cells. It was previously proposed that the release of free metal ions from metallic nanoparticle suspensions represented a major source of toxicity for the growth rate of aquatic microorganisms $[18,19]$. However, it is difficult to determine if the release of free metal ions from nanoparticles is the only contribution to the toxicity impact in the algal cellular system. Indeed, solubilisation of nanoparticles can take place either in the media or inside the cell, which possess an acidic $\mathrm{pH}$ environment favorable for particle solubility [20]. Therefore, another hypothesis is that SPION may also contribute directly to the toxicity impact. Recently, it was suggested for direct toxicity mechanisms of nanoparticles to induce a direct alteration of 


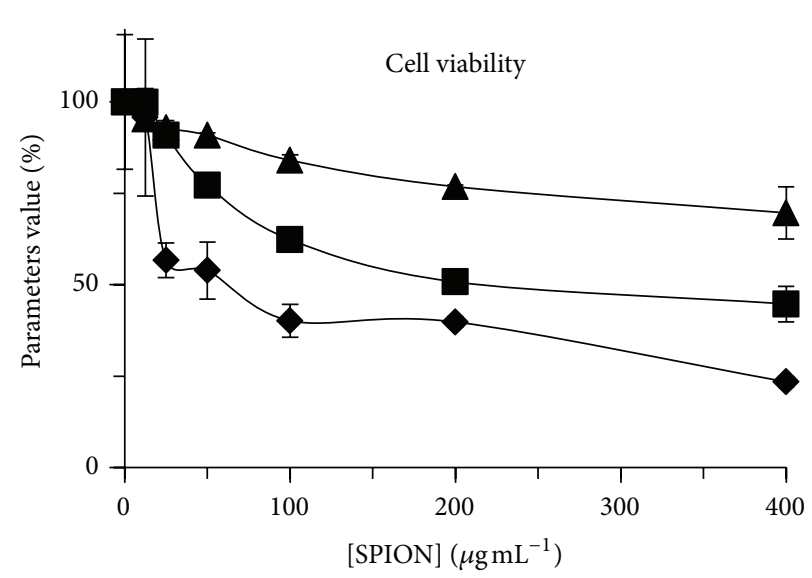

(a)

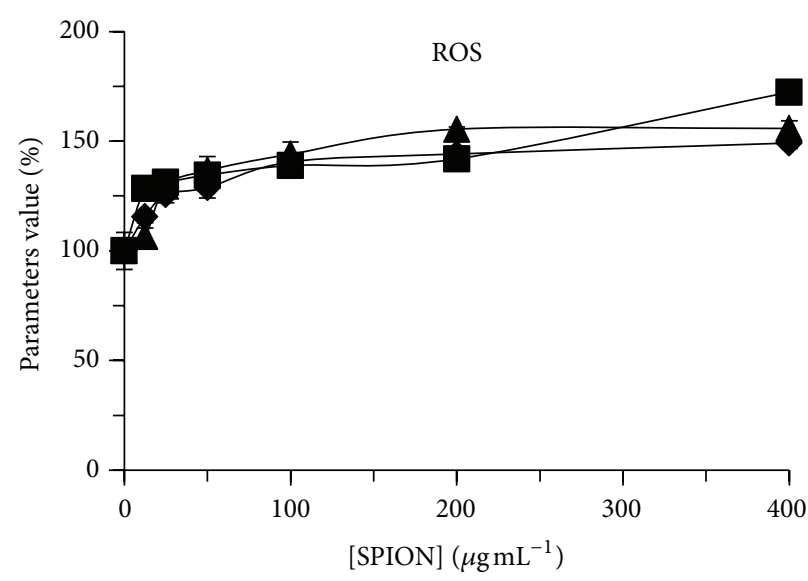

(b)

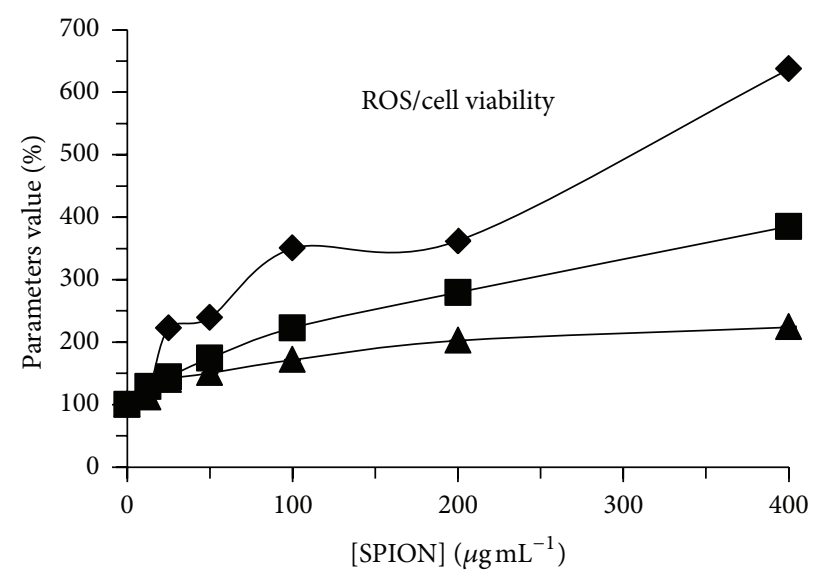

(c)

FIgURE 9: Change in the production of reactive oxygen species (ROS), cellular viability, and the ratio ROS/viable cells for Chlorella vulgaris

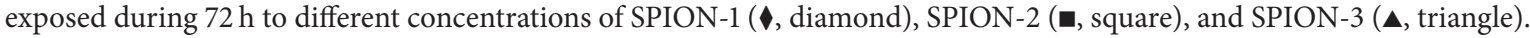

cellular exchanges with the media due to particles binding on cell membrane [21]. It was also shown for bioaccumulated $\mathrm{Fe}_{3} \mathrm{O}_{4}$ nanoparticles to cause direct toxic effects inside plant cells $[8]$.

Moreover, the increase of production of reactive oxygen species per cell viability was related to the increasing exposure concentration of SPION, indicating that the induction of cellular oxidative stress was caused by the bioaccumulation of $\mathrm{Fe}, \mathrm{Co}$, and $\mathrm{Zn}$. Indeed, it was shown in previous studies that metallic nanoparticles can cause the formation of ROS via the Fenton reaction or the disruption of major physiological processes $[22,23]$. Also, the charged metallic surface of nanoparticles can trigger the formation of ROS by catalytic reduction of oxygen into superoxide anion, leading to oxidative damage into proteins, lipids, nucleic acids, and pigments [24].

When algal cells of C. vulgaris were exposed during $72 \mathrm{~h}$ to different concentrations of SPION suspensions, the relative cellular division rate was strongly inhibited for SPION-1 compared to SPION-2 and SPION-3. Under these treatment conditions, the production of ROS per viable cells was the highest for SPION-1. Indeed, Fe is well known to generate in cell free radical oxidations causing lipid peroxidation [25]. Furthermore, the change of fluorescence parameter P.I. indicated a stronger inhibition of photosynthesis for SPION1. Therefore, according to the change of these biomarkers, the toxicity impact in algal cells of $C$. vulgaris was the strongest for SPION-1 suspensions.

4.2. Significance of Biochemical Biomarkers. In this study, two different biochemical biomarkers were used to characterize the toxicity of SPION: the production of ROS per viable cells and the photosynthetic-based fluorescence parameters. The change of parameter ROS/cell viability permitted determining the potential source of cellular toxicity causing the inhibition of cell division rate. On the other hand, fluorescence parameters related to PSII photochemical reactions have been shown to be sensitive biomarkers of SPION toxicity to C. vulgaris cells. Indeed, the $\mathrm{Chl} a$ fluorescence emission is demonstrated to be related to water-splitting system functions at PSII reaction center and to oxidoreduction states of electron transport carriers [26, 27]. Therefore, our results showed evidence for SPION to cause inhibitory effects on the PSII water-splitting system and the photoactivation of PSII 
reaction centers. In comparison to other fluorescence indicators, the performance index of PSII activity, representing an integrative indicator of all PSII photochemical reactions [17], was the most sensitive biomarker of the deterioration of PSII functions caused by SPION toxicity.

\section{Conclusion}

Nowadays, a large quantity of metallic nanoparticles is produced and their toxic potential as hazardous contaminants in aquatic environment needs to be investigated in order to develop specific bioassays for nanoparticles toxicity assessment. In this regard, microalgae represent sensitive organisms to be used in bioassay toxicity testing for the assessment of hazardous materials. In this toxicological investigation, we clearly showed the potential source of toxicity of three SPION suspensions, having different chemical compositions. The algal model C. vulgaris demonstrated to be a valuable bioindicator of SPION cellular toxicity which was indicated by the deterioration of photochemical activities of photosynthesis, the induction of oxidative stress, and the inhibition of cell division rate. Therefore, this work permitted characterising the cellular toxicity impact of these SPION with different biomarkers. A good understanding of these toxicological interactions will permit better understanding the risk of SPION toxicity for aquatic organisms.

\section{Abbreviations}

\section{Chl: Chlorophyll \\ NP: Nanoparticles \\ PEA: Plant Efficiency Analyzer \\ PSII: Photosystem II \\ ROS: Reactive oxygen species}

SPION: Superparamagnetic iron oxide nanoparticles

TEM: Transmission electron microscope.

\section{Conflict of Interests}

The authors declare that they have no conflict of interests.

\section{Acknowledgments}

This work was performed at the Department of Chemistry (UQAM). The authors acknowledge the financial support provided by both the Faculty of Sciences and the Department of Chemistry (UQAM). The authors wish to thank L. Ben Taherc, L. Samia Smiric, and H. Abdelmelekb for providing nanopowder of $\mathrm{Fe}_{3} \mathrm{O}_{4}, \mathrm{Co}_{0.2} \mathrm{Zn}_{0.8} \mathrm{Fe}_{2} \mathrm{O}_{4}$, and $\mathrm{Co}_{0.5} \mathrm{Zn}_{0.5} \mathrm{Fe}_{2} \mathrm{O}_{4}$.

\section{References}

[1] A. Ito, M. Shinkai, H. Honda, and T. Kobayashi, "Medical application of functionalized magnetic nanoparticles," Journal of Bioscience and Bioengineering, vol. 100, no. 1, pp. 1-11, 2005.

[2] D. L. Huber, "Synthesis, properties, and applications of iron nanoparticles," Small, vol. 1, no. 5, pp. 482-501, 2005.
[3] N. Singh, G. J. S. Jenkins, R. Asadi, and S. H. Doak, "Potential toxicity of superparamagnetic iron oxide nanoparticles (SPION)," Nano Reviews, vol. 1, Article ID 5358, 2010.

[4] I. Bhatt and B. N. Tripathi, "Interaction of engineered nanoparticles with various components of the environment and possible strategies for their risk assessment," Chemosphere, vol. 82, no. 3, pp. 308-317, 2011.

[5] M. Delay and F. H. Frimmel, "Nanoparticles in aquatic systems," Analytical and Bioanalytical Chemistry, vol. 402, no. 2, pp. 583592, 2012.

[6] E. N. Taylor, K. M. Kummer, N. G. Durmus, K. Leuba, K. M. Tarquinio, and T. J. Webster, "Superparamagnetic iron oxide nanoparticles (SPION) for the treatment of antibiotic-resistant biofilms," Small, vol. 8, pp. 3016-3027, 2012.

[7] H. Zhu, J. Han, J. Q. Xiao, and Y. Jin, "Uptake, translocation, and accumulation of manufactured iron oxide nanoparticles by pumpkin plants," Journal of Environmental Monitoring, vol. 10, no. 6, pp. 713-717, 2008.

[8] Y. K. Mushtaq, "Effect of nanoscale $\mathrm{Fe}_{3} \mathrm{O}_{4}, \mathrm{TiO}_{2}$ and carbon particles on cucumber seed germination," Journal of Environmental Science and Health A, vol. 46, no. 14, pp. 1732-1735, 2011.

[9] X. Chen, X. Zhu, R. Li, H. Yao, Z. Lu, and X. Yang, "Photosynthetic toxicity and oxidative damage induced by nano- $\mathrm{Fe}_{3} \mathrm{O}_{4}$ on Chlorella vulgaris in aquatic environment," Open Journal of Ecology, vol. 2, pp. 21-28, 2012.

[10] R. Rippka, J. Deruelles, and J. B. Waterbury, "Generic assignments, strain histories and properties of pure cultures of cyanobacteria," Journal of General Microbiology, vol. 111, no. 1, pp. 1-61, 1979.

[11] H. Basti, L. Ben Tahar, L. S. Smiri et al., "Catechol derivativescoated $\mathrm{Fe}_{3} \mathrm{O}_{4}$ and $\gamma-\mathrm{Fe}_{2} \mathrm{O}_{3}$ nanoparticles as potential MRI contrast agents," Journal of Colloid and Interface Science, vol. 341, no. 2, pp. 248-254, 2010.

[12] W. A. Hoffmann and H. Poorter, "Avoiding bias in calculations of relative growth rate," Annals of Botany, vol. 90, no. 1, pp. 3742, 2002.

[13] I. B. Gerber and I. A. Dubery, "Fluorescence microplate assay for the detection of oxidative burst products in tobacco cell suspensions using $2^{\prime}, 7^{\prime}$-dichlorofluorescein," Methods in Cell Science, vol. 25, no. 3-4, pp. 115-122, 2004.

[14] P. Mayer, R. Cuhel, and N. Nyholm, "A simple in vitro fluorescence method for biomass measurements in algal growth inhibition tests," Water Research, vol. 31, no. 10, pp. 2525-2531, 1997.

[15] A. R. Wellburn, "The spectral determination of chlorophylls $a$ and $b$, as well as total carotenoids, using various solvents with spectrophotometers of different resolution," Journal of Plant Physiology, vol. 144, no. 3, pp. 307-313, 1994.

[16] L. Force, C. Critchley, and J. J. S. Van Rensen, "New fluorescence parameters for monitoring photosynthesis in plants 1: the effect of illumination on the fluorescence parameters of the JIP-test," Photosynthesis Research, vol. 78, no. 1, pp. 17-33, 2003.

[17] R. J. Strasser, A. Srivastava, and M. Tsimilli-Michael, "Analysis of the chlorophyll a fluorescence transient," in Chlorophyll fluorescence A signature of Photosynthesis, Advances in Photosynthesis and respiration, G. G. Papageorgiou, Ed., pp. 321-362, Kluwer Academic, Dodrecht, The Netherlands, 2004.

[18] N. M. Franklin, N. J. Rogers, S. C. Apte, G. E. Batley, G. E. Gadd, and P. S. Casey, "Comparative toxicity of nanoparticulate $\mathrm{ZnO}$, bulk $\mathrm{ZnO}$, and $\mathrm{ZnCl}_{2}$ to a freshwater microalga (Pseudokirchneriella subcapitata): the importance of particle 
solubility," Environmental Science and Technology, vol. 41, no. 24, pp. 8484-8490, 2007.

[19] V. Aruoja, H.-C. Dubourguier, K. Kasemets, and A. Kahru, "Toxicity of nanoparticles of $\mathrm{CuO}, \mathrm{ZnO}$ and $\mathrm{TiO}_{2}$ to microalgae Pseudokirchneriella subcapitata," Science of the Total Environment, vol. 407, no. 4, pp. 1461-1468, 2009.

[20] A. M. Studer, L. K. Limbach, L. Van Duc et al., "Nanoparticle cytotoxicity depends on intracellular solubility: comparison of stabilized copper metal and degradable copper oxide nanoparticles," Toxicology Letters, vol. 197, no. 3, pp. 169-174, 2010.

[21] S. Lin, P. Bhattacharya, N. C. Rajapakse, D. E. Brune, and P. C. $\mathrm{Ke}$, "Effects of quantum dots adsorption on algal photosynthesis," Journal of Physical Chemistry C, vol. 113, no. 25, pp. $10962-$ 10966, 2009.

[22] T. Xia, M. Kovochich, J. Brant et al., "Comparison of the abilities of ambient and manufactured nanoparticles to induce cellular toxicity according to an oxidative stress paradigm," Nano Letters, vol. 6, no. 8, pp. 1794-1807, 2006.

[23] X. Hu, S. Cook, P. Wang, and H.-M. Hwang, "In vitro evaluation of cytotoxicity of engineered metal oxide nanoparticles," Science of the Total Environment, vol. 407, no. 8, pp. 3070-3072, 2009.

[24] W. J. Stark, "Nanoparticles in biological systems," Angewandte Chemie-International Edition, vol. 50, no. 6, pp. 1242-1258, 2011.

[25] F. Q. Schafer, S. Y. Qian, and G. R. Buettner, "Iron and free radical oxidations in cell membranes," Cellular and Molecular Biology, vol. 46, no. 3, pp. 657-662, 2000.

[26] D. Dewez, N. A. Ali, F. Perreault, and R. Popovic, "Rapid chlorophyll a fluorescence transient of Lemna gibba leaf as an indication of light and hydroxylamine effect on photosystem II activity," Photochemical and Photobiological Sciences, vol. 6, no. 5, pp. 532-538, 2007.

[27] D. Dewez, N. Boucher, F. Bellemare, and R. Popovic, "Use of different fluorometric systems in the determination of fluorescence parameters from spinach thylakoid membranes being exposed to atrazine and copper," Toxicological and Environmental Chemistry, vol. 89, no. 4, pp. 655-664, 2007. 

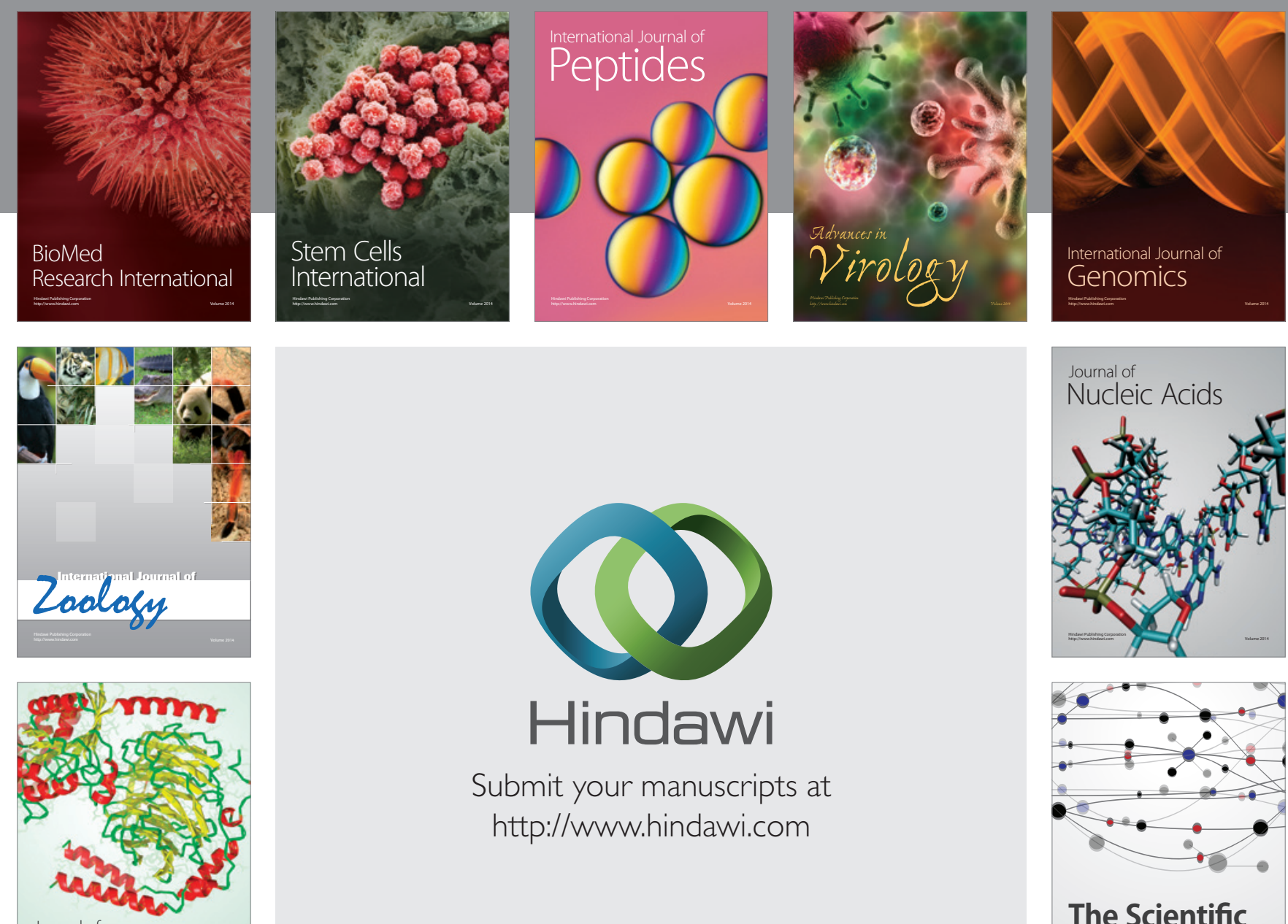

Submit your manuscripts at

http://www.hindawi.com

Journal of
Signal Transduction
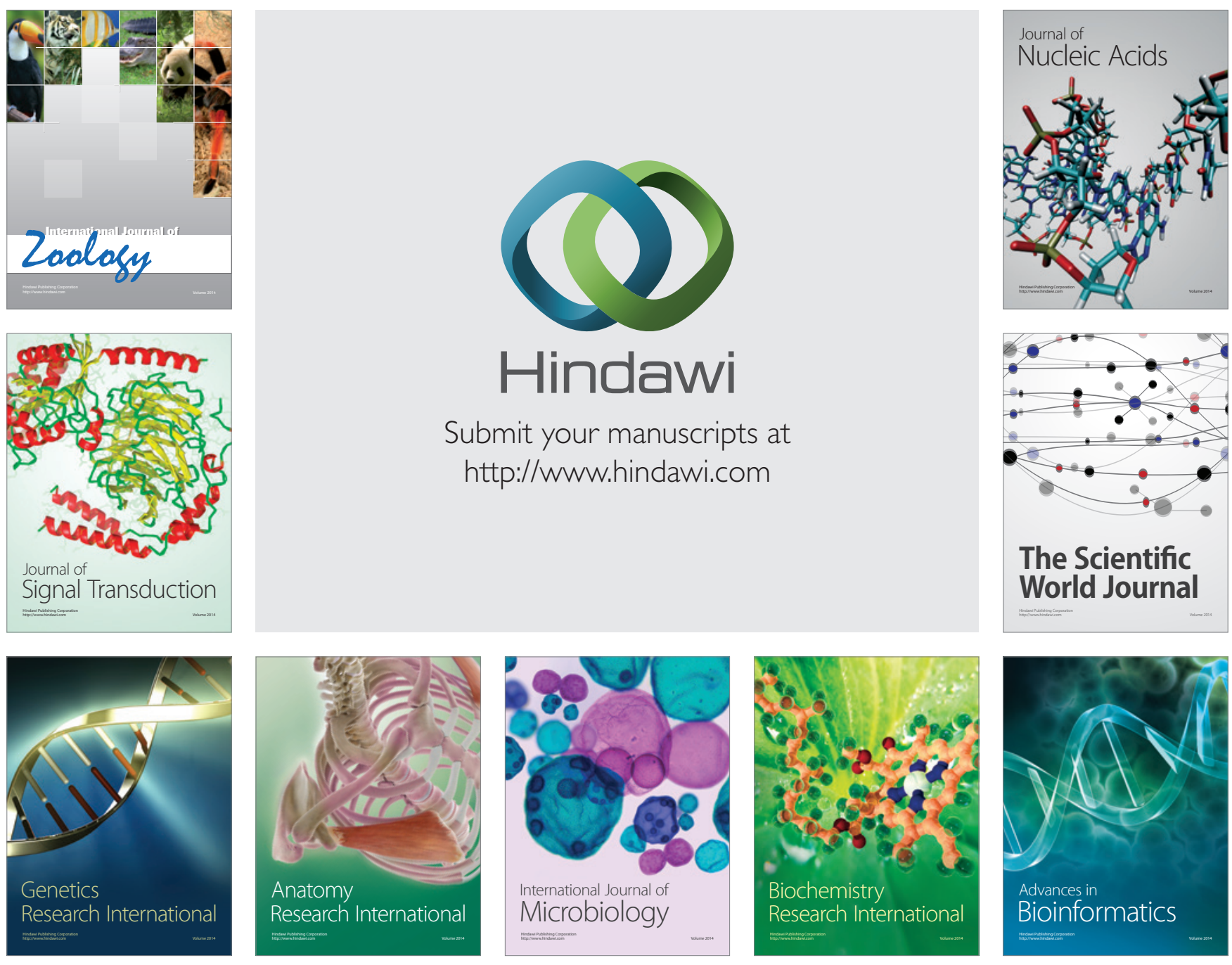

The Scientific World Journal
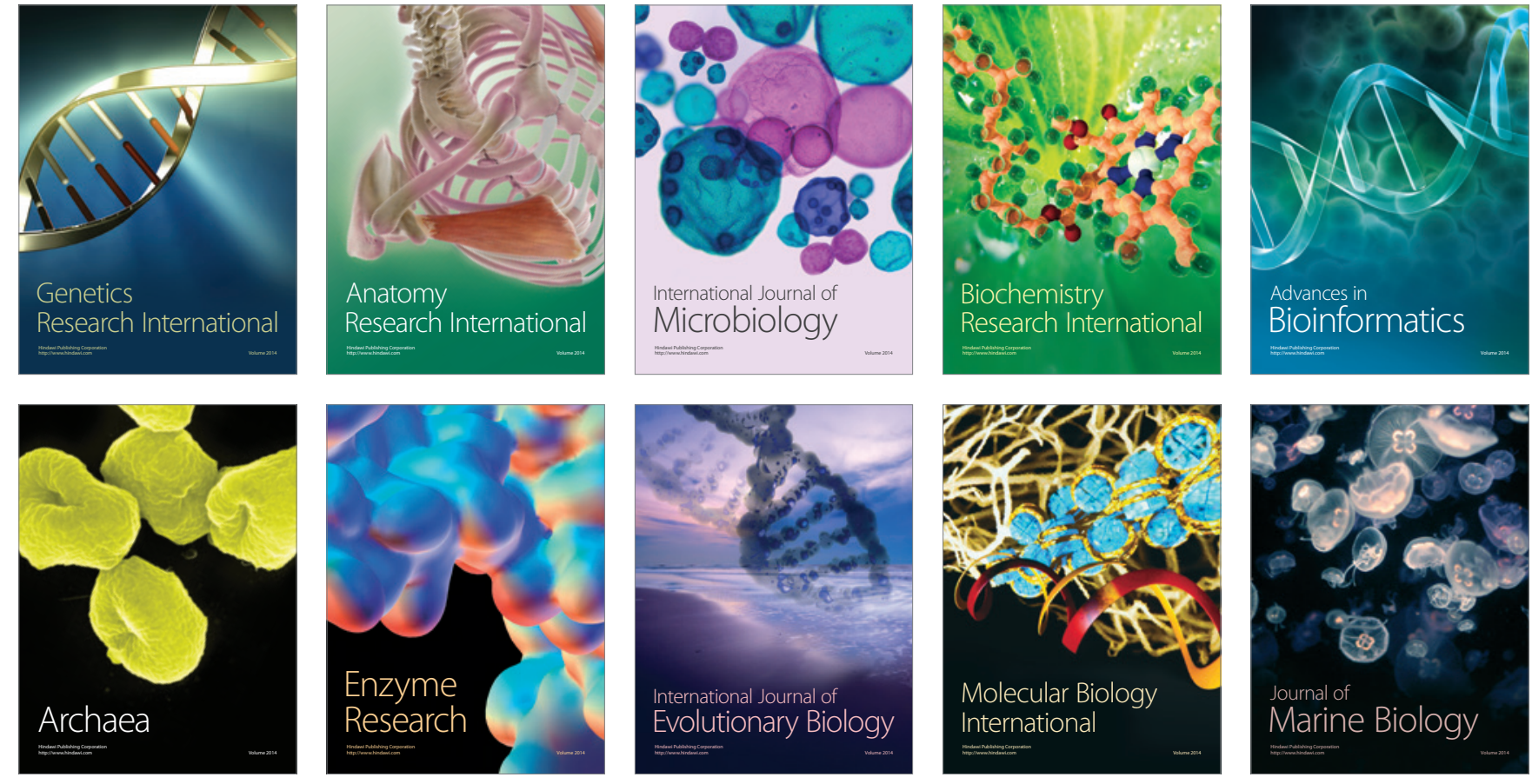